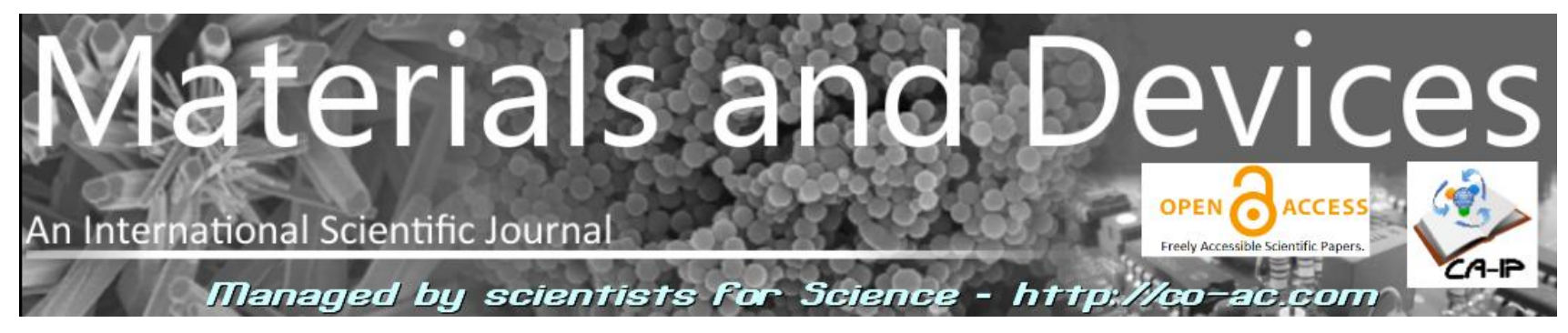

Article type: R- Invited review article (CASAMANSUN2018)

\title{
Design and optimization of silicon nanostructures
}

\author{
B. Dieng (1), M. Beye (1), M. Toure (2), D. Diouf (1), D. Kobor (2), A. S. \\ Maiga (1) \\ (1) LEITER, Gaston Berger University, Senegal \\ (2) LCPM, Assane Seck University, Senegal
}

\section{Corresponding author: dieng.babacar@ugb.edu.sn}

RECEIVED: 14 September 2018 / RECEIVED IN FINAL FORM: 14 February 2019 / ACCEPTED: 16 February 2019

\begin{abstract}
: in this work, recent advances in various silicon nanostructures used in crystalline silicon solar cells for antireflection and light trapping are reviewed. Simulations and optimizations are also performed for the most relevant of these nanostructures. The results showed that nanocones and nanoparaboloids outperform nanopillars and give almost the same antireflective performance, reducing the average reflectance of the crystalline silicon surface below $2 \%$ in the wavelength range $300-1100 \mathrm{~nm}$ and under normal incidence. This reflectance is also found to stay below $4 \%$ for angles of incidence lower than $60^{\circ}$ and for the averaged $s$ and $p$ light polarization. As a result, short-circuit current densities of 41.62 and $41.96 \mathrm{~mA} / \mathrm{cm}^{2}$, can be expected for a silicon solar cell decorated with these two nanostructures, respectively. Finally, we described the formation of silicon nanocones via nanowires by metal assisted chemical etching.
\end{abstract}

Keywords: SILICON, NANOSTRUCTURES, ANTIREFLECTION, LIGHT TRAPPING, CHEMICAL ETCHING

\begin{tabular}{|l|}
\hline Cite this article: authors, OAJ Materials and Devices, Vol 4 \#1, \\
\hline 0129 (2019) - DOI: $10.23647 /$ ca.md20190129
\end{tabular}




\section{Introduction}

Today's state-of-the-art R\&D best monocrystalline (multicrystalline) silicon solar cell and module can deliver power conversion efficiencies (PCE) of about $26.7 \%(21.9 \%)$ and $24.4 \%(19.9 \%)$, respectively [1]. The increased production volumes and the associated maturity of the crystalline silicon-based technology have brought the cost of silicon PV modules down to 0.4 US $\$ / W p$ [2]. However, the actual efficiency (cost) is not yet high (low) enough to guarantee a widespread adoption of solar by consumers. Further efficiency enhancement and cost reduction, through optimization of device structure, simplification of device fabrication, as well as reduction of material usage, are required [3].

The nanostructuring of the silicon surface has been found to be an efficient way to eliminate the frontsurface reflection and, simultaneously, to increase the absorption in silicon solar cells [4]. Optimized silicon nanostructure arrays exhibit not only excellent antireflective and light trapping properties [6-9], but also provide other PV relevant functionalities such as hydrophobicity [10, 11]. Therefore, they are more and more used in solar cells for efficiency enhancement [5] and cost reduction [3].

In this work, recent advances in various silicon nanostructures used for antireflection and light trapping in crystalline silicon solar cells, such as nanopyramids, nanopillars, nanocones and nanoparaboloids, are first reviewed. Then, the most relevant of these nanostructures are simulated and optimized for performance enhancement. Finally, the formation of silicon nanocones by metalassisted chemical etching (MACE) is described.

\section{Recent advances in silicon nanostructures used for antireflection and light trapping}

\section{II.1. Silicon nanopyramids}

Pyramids have long been the dominant structure at the front surface of monocrystalline-silicon solar cells. Pyramidal silicon microstructures $(\sim 10 \mu \mathrm{m}$ thickness) provide a relatively low surface area and a good light trapping capability, achieved through multiple reflection of the incident light in the various facets of the pyramidal structure $[12,13]$. This results in average reflectance values of less than $10 \%$ in the spectral range $300-1100 \mathrm{~nm}$ and an appreciable increase in the solar cell PCE. Also, inverted pyramids have been found to outperform upright pyramids due to the fact that most of the incident rays bounce several times (at least three) on the walls of the inverted pyramids but only twice between conventional random upright pyramids. Therefore, the length of the optical path and the probability of light absorption are higher in the inverted pyramid structure [12, 14-16]. In addition to superior light trapping capability, the inverted pyramid structure is characterized by recessed and wide deeps, making this texture more suitable for conformal coating and filling. The coverage of passivation layers (for example hydrogenated amorphous silicon (a-Si:H) $[17,18]$ and silicon nitride ( $\mathrm{SiNx}$ ) layers [13]) or thin film solar cells (for example a thin film perovskite solar cell [19]) and the filling of metal electrodes in photovoltaic devices [13] demonstrated the compatibility of inverted pyramids with subsequent process steps in the manufacture of solar cells.

Recently, with the trend toward ultrathin crystalline silicon cells, pyramidal microstructures commonly applied on thick crystalline silicon cells become unsuitable and the implementation of nanopyramids is proving to be more effective [13, 20-24]. Metal (e.g. Au, Ag, Cu)-assisted chemical etching [13, 16] or combination of lithography and wet chemical etching are principally used to fabricate inverted nanopyramids on silicon wafers $[17,20,22,24]$. The different techniques used, the optimized structural parameters found and the performance obtained are summarized in Table 1. 
Table 1: Techniques, parameters and performance of inverted nanopyramid structure on a silicon wafer.

\begin{tabular}{|c|c|c|}
\hline Techniques & Parameters & Performance \\
\hline $\begin{array}{l}\text { Laser interference lithography } \\
\text { and wet chemical etching [20]. }\end{array}$ & $\begin{array}{l}\text { period }=700 \mathrm{~nm} \\
\text { spacing }=100 \mathrm{~nm}\end{array}$ & $\begin{array}{l}37.5 \mathrm{~mA} / \mathrm{cm}^{2} \text { of Jsc for } 10 \mu \mathrm{m} \text {-thick c-Si } \\
\text { (over } 30 \text {-fold reduction in material usage) }\end{array}$ \\
\hline $\begin{array}{l}\text { Laser interference lithography } \\
\text { and subsequent combined dry } \\
\text { and wet etching [22] }\end{array}$ & $\begin{array}{l}\text { period }=700 \mathrm{~nm} \\
\text { spacing }=100 \mathrm{~nm} \\
\text { depth }=475 \mathrm{~nm}\end{array}$ & $\begin{array}{l}\text { R below } 10 \% \text { over the broad } \lambda \text { range } 300 \\
-1200 \mathrm{~nm} \\
\text { Increase in efficiency by } 67 \%\end{array}$ \\
\hline $\begin{array}{lc}\text { Colloidal lithography } & \text { and } \\
\text { anisotropic wet etching [23] } & \end{array}$ & period $=1400 \mathrm{~nm}$ & $\begin{array}{l}\text { Increase in Jsc by } 76 \% \text { for } 20-\mu \mathrm{m} \text {-thick c- } \\
\mathrm{Si}\left(39.86 \mathrm{~mA} / \mathrm{cm}^{2} \text { vs } 22.63 \mathrm{~mA} / \mathrm{cm}^{2} \text { for }\right. \\
\text { the flat counterpart) }\end{array}$ \\
\hline $\begin{array}{l}\text { Laser interference lithography } \\
\text { and reactive ion etching (RIE) } \\
\text { and wet etching [24] }\end{array}$ & $\begin{array}{l}\text { width } \sim 450 \mathrm{~nm} \\
\text { height } \sim 310 \mathrm{~nm} \\
\text { spacing } \sim 125 \mathrm{~nm}\end{array}$ & $\begin{array}{l}\text { Increase in Jsc by } 11.45 \% \text { (from } 29.422 \text { to } \\
32.793 \mathrm{~mA} / \mathrm{cm}^{2} \text { ) }\end{array}$ \\
\hline $\begin{array}{l}\text { Cu-assisted anisotropic etching } \\
\text { [13] }\end{array}$ & $\begin{array}{l}\text { Random inverted } \\
\text { pyramids }\end{array}$ & $\begin{array}{l}\text { Mean } R \text { down to } \sim 4.4 \% \text { over the } \lambda \text { range } \\
300-1000 \mathrm{~nm} ; \\
\text { A high conversion efficiency of } 18.87 \%\end{array}$ \\
\hline colloidal lithography [18] & $\begin{array}{l}\text { diameter } \sim 600 \mathrm{~nm} \\
\text { depth } \sim 530 \mathrm{~nm} \\
\text { aspect ratio (length } \\
\text { by diameter) } \\
0.9-1\end{array}$ & $\begin{array}{l}\text { Increase in the light path by } 7.5 \text { times; } \\
\text { Efficiency of } 8.6 \% \text { on } 830 \text { nm-thick } \\
\text { monocrystalline silicon }\end{array}$ \\
\hline
\end{tabular}

$J_{\mathrm{SC}}=$ short-circuit current density; $R=$ reflectance $; \lambda=$ wavelength .

The advantages of excellent antireflection and light-trapping capabilities, an inherent low parasitic surface area, a negligible surface damage (less material damage), a scalable fabrication capability and good compatibility with subsequent process steps, make inverted nanopyramids a promising alternative for high-performance and cost-effective crystalline silicon thin film cells [23].

\section{II.2. Silicon nanopillars}

Silicon nanopillar arrays with different pillar profiles have been found to exhibit excellent broadband, omnidirectional antireflective, and hydrophobicity properties due partly to the graded effective refractive index profile provided by the structure. Their great potential in improving the PCE and lowering the cost of crystalline silicon solar cells has been theoretically and experimentally demonstrated [7-9, 25-35]. Furthermore, it has been shown that the shape, height and period of silicon nanopillar arrays have a great influence on their antireflective properties [8, 28-30, 34]. Sharper pillars would lead to sharper minimum in the reflectance spectrum and so to a surface that is less suitable for broadband applications [8]. In fact, a close relation exists between the nanopillar shape and the refractive index gradient. Nanopillars with a tapered profile produce a smooth transition of the refractive index from the top to the bottom of the structure, whereas nanopillars with a cylindrical profile produce a larger discontinuity at the interface which causes more reflection [34]. Also, it was observed that the taller the pillars, the lower the reflectance, but the higher the fabrication cost. This is because at small pillar height, the reflectance is high as the interface appears abrupt to incident light [8]. As for the period, it was shown that close-packed nanopillar arrays exhibit better antireflective performance than non-close-packed arrays due to a smoother refractive index gradient [30]. However, for single-diameter nanopillars, that are similar to nanowires, it was found that increasing the material filling ratio leads simultaneously to an increase of the reflectance and a decrease in the transmittance, with the absorption showing a strong diameter dependence [36]. The light absorption of nanopillar arrays is either determined by the material filling ratio or by transverse resonance leaky modes depending on the input wavelength. A properly designed multi-diameter 
nanopillar array was found to compete with a nanocone array on broadband light absorption capability, showing the same light absorption level when the number of the segment $N=7$ [37].

Various techniques are used to fabricate silicon nanopillars such as the combination of reactive-ion etching (RIE) with processes as self-assembly [25], spin coating [26], nanoimprint lithography [27], colloidal lithography [28], electron beam lithography [35], and inductively coupled plasma reactive-ion etching (ICP-RIE). The different techniques used, the optimized structural parameters found and the performance obtained are summarized in Table 2.

Table 2: Techniques, parameters and performance of nanopillar structures on a silicon wafer.

\begin{tabular}{|c|c|c|}
\hline Techniques [References] & Parameters & Performance \\
\hline $\begin{array}{l}\text { Self-assembly of polystyrene sphere } \\
\text { and RIE [25] }\end{array}$ & $\begin{array}{l}\text { height }=260 \mathrm{~nm} \\
\text { aspect ratio }=0.9\end{array}$ & $\mathrm{R}<8 \%$ for $600 \leq \lambda \leq 1300 \mathrm{~nm}$ \\
\hline spin-coating and RIE [26] & $\begin{array}{l}\text { height }=2200 \mathrm{~nm} \\
\text { period }=380 \mathrm{~nm}\end{array}$ & $\mathrm{R}<2.5 \%$ for $350 \leq \lambda \leq 1650 \mathrm{~nm}$ \\
\hline $\begin{array}{l}\text { Nanoimprint lithography (NIL) and } \\
\text { deep RIE (DRIE) [27] }\end{array}$ & $\begin{array}{l}\text { diameter }<40 \mathrm{~nm} \\
\text { height }=1.5 \mu \mathrm{m}\end{array}$ & $\begin{array}{l}\text { Wide-area fabrication of high aspect } \\
\text { ratio silicon pillar arrays with straight } \\
\text { sidewalls }\end{array}$ \\
\hline $\begin{array}{l}\text { Colloidal lithography (or anodic } \\
\text { aluminum oxide) and metal-assisted } \\
\text { chemical etching [28] }\end{array}$ & $\begin{array}{l}\text { period }=100 \mathrm{~nm} \\
\text { diameter }=60 \mathrm{~nm}\end{array}$ & $\begin{array}{l}\text { Average specular } R \text { of } 0.7 \% \text { for } 200 \leq \lambda \\
\leq 1900 \mathrm{~nm} \text { and for } \theta \text { up to } 70^{\circ} \text { (s- and } \\
\text { p-polarized light) }\end{array}$ \\
\hline $\begin{array}{l}\text { Cryogenic inductively coupled } \\
\text { plasma reactive-ion etching [25]. }\end{array}$ & $\begin{array}{l}\text { height } \sim 800 \mathrm{~nm} \\
\text { width }=200 \mathrm{~nm} \\
\text { bottom diameter } \\
\sim 200 \mathrm{~nm} \\
20 \mathrm{~nm} \text { of } \mathrm{Al}_{2} \mathrm{O}_{3} \text { film } \\
\text { (passivation) }\end{array}$ & $\begin{array}{l}R<1 \% \text { for } 300 \leq \lambda \leq 1000 \mathrm{~nm} \text {; } \\
\text { Efficiency of } 22.1 \% \text {; } \\
\text { Potential increase of } 3 \% \text { in daily } \\
\text { energy production }\end{array}$ \\
\hline $\begin{array}{l}\text { Electron beam lithography and RIE } \\
\text { [35] }\end{array}$ & $\begin{array}{l}\text { width }=140 \mathrm{~nm} \\
\text { thickness }=110 \mathrm{~nm} \\
\text { spacing }=100 \mathrm{~nm}\end{array}$ & $\begin{array}{l}\text { average } R<5 \% \text { in the visible spectrum } \\
\text { for both polarizations for } 0^{\circ} \leq \theta \leq 40^{\circ}\end{array}$ \\
\hline
\end{tabular}

$\mathrm{J}_{\mathrm{SC}}=$ short-circuit current density; $\mathrm{R}=$ reflectance; $\lambda=$ wavelength; $\boldsymbol{\theta}=$ incident angle.

Strongly reduced reflection and enhanced light trapping can be achieved in thin $(<100 \mu \mathrm{m})$ crystalline silicon solar cells covered with nanopillar arrays on top of interference coatings. Optimized $\mathrm{Si}$ nanocylinders (diameter $=250 \mathrm{~nm}$, height $=150 \mathrm{~nm}$ and pitch $=450 \mathrm{~nm}$ ) on a standard $\mathrm{Si}_{3} \mathrm{~N}_{4}$ coating (thickness $=60 \mathrm{~nm}$ ) resulted in an average reflectance of $1.3 \%$ in the $450-900 \mathrm{~nm}$ spectral range and for angles of incidence up to $60^{\circ}$. This reduced reflection resulted from the coupling of Mie modes to the substrate, leading to strong preferential forward scattering due to the high-mode density in the high-index Si substrate [32]. It was shown that an efficiency as high as $21.5 \%$ can be achieved for a $20-\mu \mathrm{m}$-thick cell using this combination. This represent a significant improvement compared with the efficiency found for planar $\mathrm{c}-\mathrm{Si}$ cell with a standard $\mathrm{Si}_{3} \mathrm{~N}_{4}$ antireflection coating of the same thickness (17.5\%) [38].

\section{II.3. Silicon nanocones}

Compared with many other structures, nanocones are considered as the more optimal ones for antireflection and light trapping due to their relatively small tips that provide a smoother transition of their refractive index from air to the substrate [39-47]. Investigations of the effects of structural parameters on the optical characteristics of crystalline $\mathrm{Si}$ thin films with the surface decorated by $\mathrm{Si}$ nanocone arrays showed that the base diameter should be equal to the array periodicity for efficient solar energy harvesting, and an optimized light absorption can be realized when the nanocone height 
reaches $\sim 400 \mathrm{~nm}$. It was also shown that an ultimate efficiency of $\sim 31.5 \%$ can be achieved when the periodicity is $\sim 600 \mathrm{~nm}$ for a $800 \mathrm{~nm}$-thick Si film with a $400 \mathrm{~nm}$-high nanocone array. Moreover, this ultimate efficiency can be further increased to some extent due to the enhanced light absorption in the low energy region by appropriately increasing the Si film thickness [48]. Nanocone arrays ( $d_{\text {top }}=200$ $\mathrm{nm}$, dbot $=600 \mathrm{~nm}$, period $=600 \mathrm{~nm}$, height $50-10000 \mathrm{~nm}$ ) were found to have significantly improved solar absorption and ultimate efficiency (about 22\% higher) over nanowire arrays. Detailed simulations revealed that nanocones have superior absorption due to reduced reflection from their smaller tip and reduced transmission from their larger base. The enhanced ultimate efficiency of silicon nanocone arrays was found to be insensitive to tip diameter [49]. It was found that when the aspect ratio of the nanocones is less than two, both excellent antireflection and light scattering are obtained. The light trapping effect that increases the optical path length becomes more prominent, especially when the substrate becomes thinner [50].

Like silicon nanopillars, silicon nanocones can also be fabricated by various techniques. The different techniques used, the optimized structural parameters found and the performance obtained are summarized in Table 3.

Table 3: Techniques, parameters and performance of nanocone structures on silicon wafer.

\begin{tabular}{|c|c|c|}
\hline Techniques & Parameters & Performance \\
\hline $\begin{array}{l}\text { Nanosphere lithography and } \\
\text { RIE [39] }\end{array}$ & $\begin{array}{l}\text { corrugated Si nanocones } \\
\text { - height } \sim 590 \mathrm{~nm} \\
\text { - diameters: bottom } \sim 560 \mathrm{~nm} \text {; } \\
\text { top (tip) } \sim 80 \mathrm{~nm} \text {; } \\
\text { - aspect ratio } \sim 1.0\end{array}$ & $\begin{array}{l}\mathrm{R}<0.7 \% \text { for } 400 \leq \lambda \leq 1050 \\
\mathrm{~nm} . \\
\mathrm{R}<0.5 \% \text { for } \theta \text { up to } 70^{\circ} \text { at } \\
632.8 \mathrm{~nm} \text { for both } \mathrm{s}-\text { and } \mathrm{p}- \\
\text { polarized light. }\end{array}$ \\
\hline $\begin{array}{lr}\text { Colloidal } & \text { nanosphere } \\
\text { lithography and } & \text { single-step } \\
\text { deep RIE [40] } & \end{array}$ & $\begin{array}{l}\text { - polystyrene } \quad \text { nanoislands: } \\
\text { thickness } 50-100 \mathrm{~nm} \\
\text { - Si nano-conical frustum: dbase } \\
200 \mathrm{~nm} \text {; dtop = } 190 \mathrm{~nm} \text {; height = } \\
320 \mathrm{~nm} \text {; lattice constant=360 nm }\end{array}$ & $\begin{array}{l}\text { Average R of } 3.8 \% \text { for } 300 \leq \lambda \leq \\
400 \mathrm{~nm} \text { (vs } 9.2 \% \text { for sharp- } \\
\text { tipped nanocone structures) }\end{array}$ \\
\hline $\begin{array}{l}\text { e-beam lithography and DRIE } \\
\text { [51] }\end{array}$ & $\begin{array}{l}\text { inverted nanocones: } \\
\text { - radius } ~ 50 \mathrm{~nm} ; \\
\text { - lattice constant } 300-400 \mathrm{~nm}\end{array}$ & $\begin{array}{l}\text { Three to four-fold reduction in } \\
\text { reflection }\end{array}$ \\
\hline $\begin{array}{l}\text { Langmuir-Blodgett assembly } \\
\text { and RIE [51] }\end{array}$ & $\begin{array}{l}\text { double-sided grating: } \\
\text { - top: period }=500 \mathrm{~nm} \text {; base radius } \\
=250 \mathrm{~nm} \text {; height }=710 \mathrm{~nm} \\
\text { - bottom: period }=1000 \mathrm{~nm} \text {; base } \\
\text { radius }=475 \mathrm{~nm} \text {; height }=330 \mathrm{~nm}\end{array}$ & $\begin{array}{l}\text { Jsc of } 34.6 \mathrm{~mA} / \mathrm{cm}^{2} \text { at an } \\
\text { equivalent thickness of } 2 \mu \mathrm{m}\end{array}$ \\
\hline $\begin{array}{l}\text { Colloidal lithography } \\
\text { (Langmuir-Blodgett } \text { method) } \\
\text { and RIE [43] }\end{array}$ & diameter $=200 \mathrm{~nm}$ & $\begin{array}{l}\text { EQE }>80 \% \text { for } 400 \leq \lambda \leq 800 \\
\text { nm in a sub- } 10-\mu m \text {-thick; } \\
P C E=13.7 \%\end{array}$ \\
\hline $\begin{array}{l}\text { Two-step dry etching process } \\
\text { (RIE and DRIE [46] }\end{array}$ & & $\begin{array}{l}\text { Low } \mathrm{R} \sim 0.5 \% \text { for } 300 \leq \lambda \leq \\
1500 \mathrm{~nm}\end{array}$ \\
\hline $\begin{array}{l}\text { inductively coupled plasma- } \\
\text { reactive ion etching (ICP-RIE) } \\
\text { [47] }\end{array}$ & $\begin{array}{l}\text { height }=230 \mathrm{~nm} \\
\text { spacing }=52 \mathrm{~nm}\end{array}$ & $\begin{array}{l}\text { Average } R<1 \% \text { at } \theta=45^{\circ} \text { for } \\
400 \leq \lambda \leq 1000 \mathrm{~nm} \\
\text { Average } R<4 \% \text { for } \theta<60^{\circ} \text {; } \\
\text { Improvement of the Jsc (from } 22 \\
\text { to } 33 \mathrm{~mA} / \mathrm{cm}^{2} \text { ) and the PCE } \\
\text { (from } 8.7 \text { to } 13.1 \% \text { ) by } 50 \%\end{array}$ \\
\hline
\end{tabular}

$\mathrm{J}_{\mathrm{Sc}}=$ short-circuit current density; $R=$ reflectance $\boldsymbol{\lambda}=$ wavelength $\boldsymbol{\theta}=$ incident angle; $\mathrm{EQE}=$ external quantum efficiency; $P C E$ = power conversion efficiency. 


\section{II.4. Silicon nanoparaboloids}

Paraboloid-shaped nanostructures have been found to be superior to pillar-shaped and cone-shape nanostructures, minimizing the reflectivity for a much broader spectral range, due to a linear change of the effective refractive index from air to the substrate [53]. K. Shinotsuka et al. numerically simulated both convex and concave paraboloids and found that the surface reflectivity is drastically decreased when a step is introduced in the taper. The optimization of the step position (at $100 \mathrm{~nm}$ height for convex and $150 \mathrm{~nm}$ height for concave) and depth (7 nm for convex and $6 \mathrm{~nm}$ for concave) provided average reflectances of $0.098 \%$ ( $0.1939 \%$ without step) for convex protrusions and $0.040 \%$ $(0.2021 \%$ without step) for concave protrusions, respectively, in the visible range $(380-780 \mathrm{~nm})$ at various incident angles.

A stepped concave paraboloid, fabricated on the whole surface of a 6 in. Si wafer (sufficient size for industrial utilization) by dry etching exhibited a measured reflectance of $0.077 \%$ on average in the visible range [54].

This mini-review shows that the design and optimization of silicon nanostructures with different shapes produce different results, mainly expressed in terms of reflection minimization and short-circuit current maximization. The next section deals with the simulation and optimization of the most relevant silicon nanostructures for solar cells.

\section{Simulation and optimization of silicon nanostructures}

In this work, the transfer matrix method [55] is used to calculate the front reflectance from a nanostructured silicon surface. The optical constants needed for this calculation are taken from [56] for crystalline silicon. The structures under consideration are shown in figure 1 . They consist of arrays of periodic pillars (a), cones (b), truncated cones (c), and parabolas (d) designed on crystalline silicon substrate. For each structure, the geometrical parameters to optimize are principally the diameter, the height and the period.

(a)

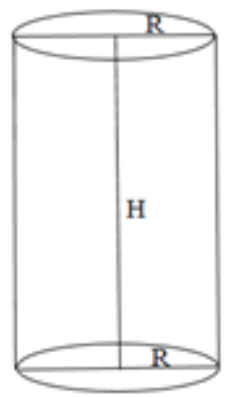

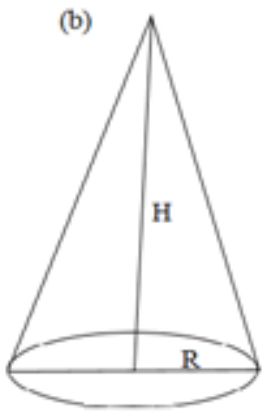

(c)

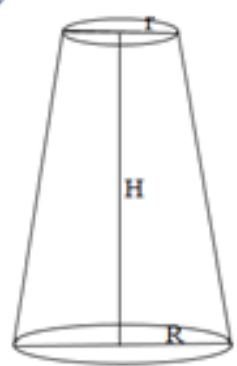

(d)

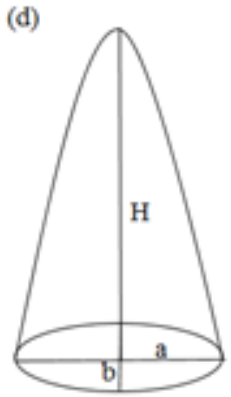

Figure 1: Schematic representations of nanostructures: (a) pillars, (b) cones, (c) truncated cones, and (d) parabolas.

To model the structures, each of them is considered as forming a composite layer consisting of silicon and air (the refractive of air index is taken $n_{\text {air }} \approx 1$ ) with a thickness equal to the height of the silicon nanostructure. Therefore, the effective refractive of the layer index is calculated in the framework of the effective medium approximation. Finally, the complex reflection coefficient, $r$, of the layer is calculated from the elements of the transfer matrix and the reflectance, $R$, is obtained as $|r|^{2}$. 
To evaluate the performance of these AR structures, the weighted reflectance of the solar radiation $\left(R_{w}\right)$ and the short-circuit current density $\left(\mathrm{J}_{s c}\right)$ that can be expected, are calculated using the following equations:

$$
\begin{gathered}
R_{w}=\frac{\int_{\lambda_{\min }}^{\lambda_{\max }} F(\lambda) \cdot \operatorname{IQE}(\lambda) \cdot R(\lambda) d(\lambda)}{\int_{\lambda_{\min }}^{\lambda_{\max }} F(\lambda) \cdot \operatorname{IQE}(\lambda) d(\lambda)} \\
J_{s c}=q \int_{\lambda_{\min }}^{\lambda_{\max }} F(\lambda) \cdot \operatorname{IQE}(\lambda) \cdot A(\lambda) d(\lambda)
\end{gathered}
$$

In these equations $F(\lambda)=\frac{I(\lambda) \cdot \lambda}{h \cdot c}$ is the incident photon flux where $I(\lambda)$ represents the solar radiation; $\operatorname{IQE}(\lambda)$ is the internal quantum efficiency of the solar cells, $R(\lambda)$ refers to the reflectance given by the AR structure, $A(\lambda)$ is the absorption in the silicon active layer, $q$ and $\lambda$ are the elementary charge and the incident wavelength, respectively. The main objective of the optimization is to reduce the weighted reflectance $\left(R_{w}\right)$ and to maximize the short circuit current density over the widest wavelength range, incident angles and for the two types ( $s$ and $p$ ) of light polarization.

Figures 2.a and 2.b show the variations of the average reflectance and the short-circuit current density, respectively, as function of the base diameter of the pillar, truncated cone and cone-shaped structures. As can be seen, low reflectance values and high short-circuit current densities are obtained with a base diameter around $100 \mathrm{~nm}$.
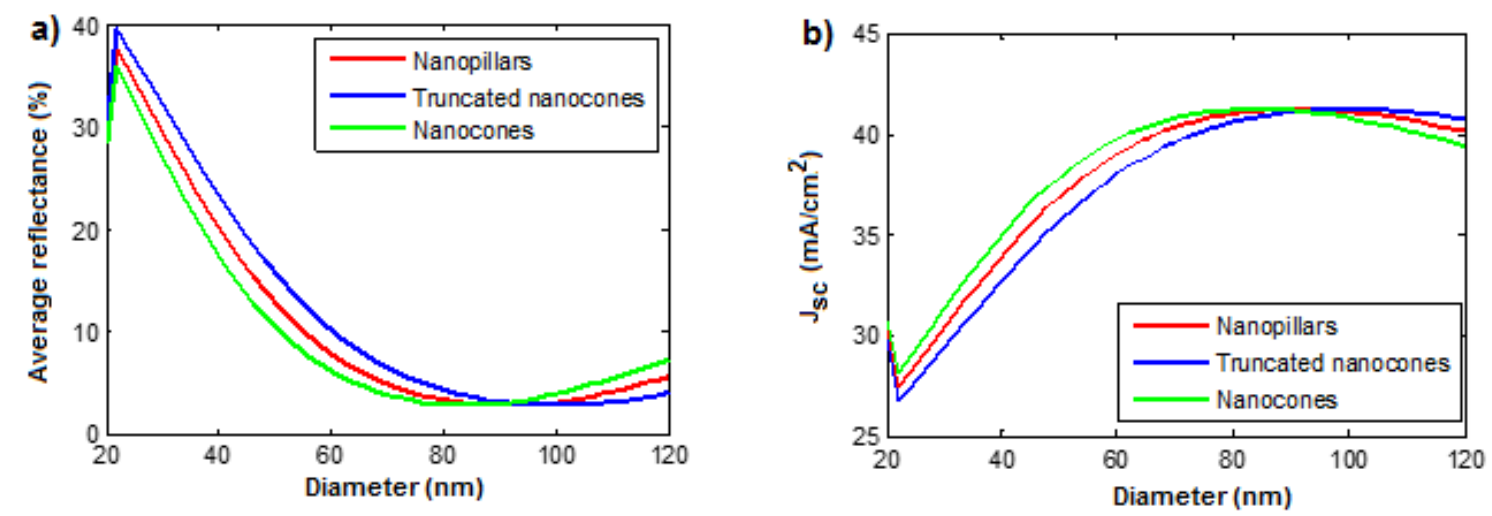

Figure 2: (a) Average reflectance and (b) short-circuit current density as a function of the structure base diameter.

For the parabola-shaped structure, the semi-major and semi-minor axis are two important parameters. The influence of these two parameters on the reflectance is depicted in Figure 3. As can be seen, the optimal values for the semi-major and the semi-minor axis are around $35 \mathrm{~nm}$ and $25 \mathrm{~nm}$, respectively.

It is known that very small and very large structures give a dense an airy structure, respectively. Thus, short and long wavelengths will not be well trapped. 


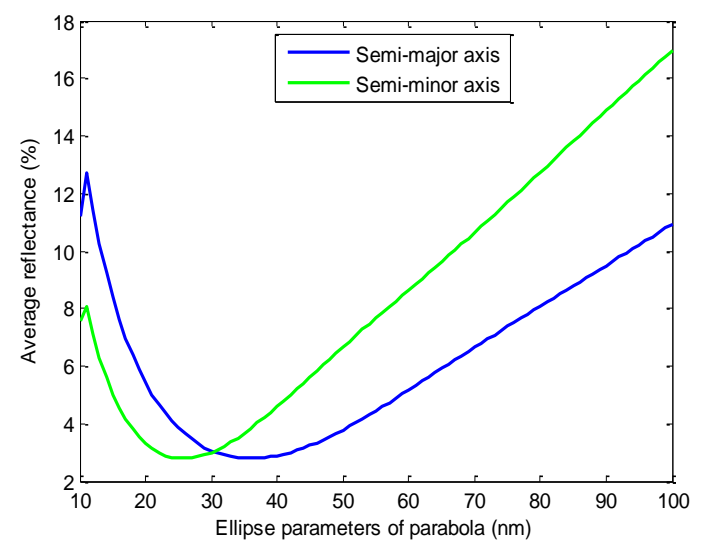

Figure 3: Average reflectance as a function of the ellipse parameters of the parabola-shaped structure.

The period of the nanostructures plays an important role in the reduction of the reflectance. Practically, the period of the nanostructures can be determined by adjusting the diameter of the nanomask used during the fabrication. Therefore, it is necessary to optimize the period before the fabrication step. Figures 4.a and 4.b show the variation of the average reflectance and the shortcircuit current density, respectively, as function of the period. As can be seen, the optimal periods of the pillar, truncated cone, cone and parabola-shaped structures are around $750 \mathrm{~nm}, 500 \mathrm{~nm}, 400 \mathrm{~nm}$ and $350 \mathrm{~nm}$, respectively. As could be expected, the optimal period depends on the structure shape. A small period is adequate for nanocone and nanoparabloid shapes because their peaks are sharp. With these optimal periods, the AR structures act as an effective medium for the longer wavelengths, as a photonic crystal for wavelengths comparable to the period and as a grating diffraction for the smaller wavelengths.
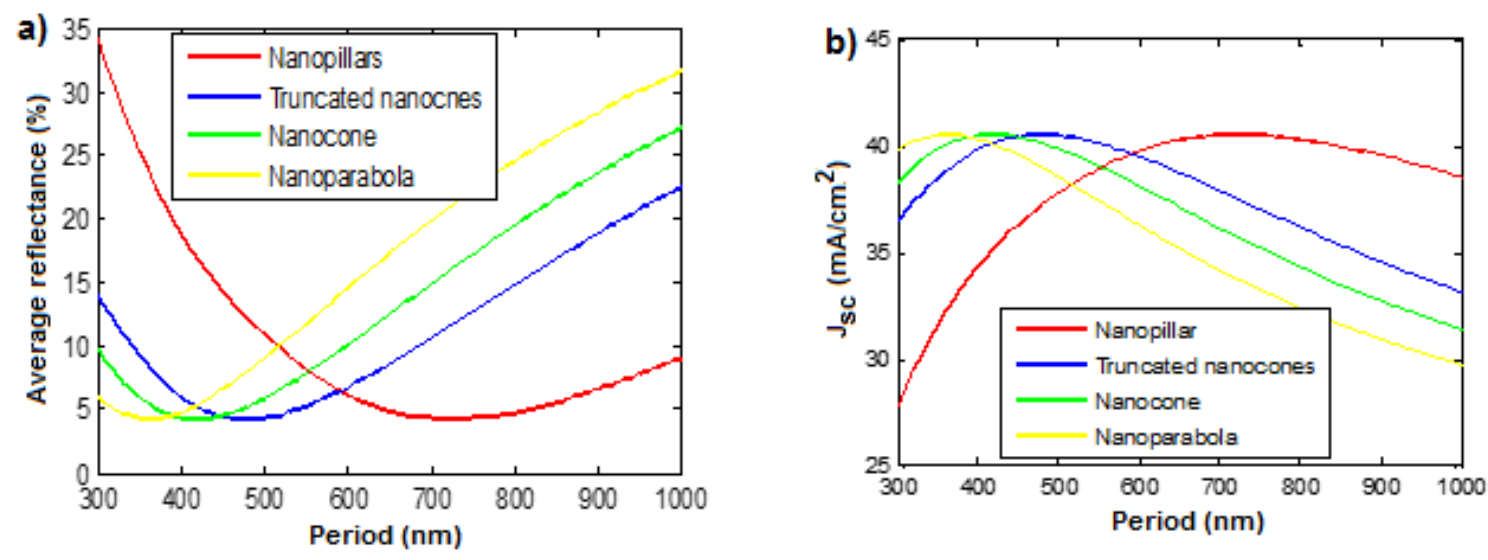

Figure 4: (a) Average reflectance and (b) short-circuit current density as a function of the period of nanostructures.

The height is another important parameters for antireflective nanostructures. Figure 5 shows that by increasing the height of the nanostructures, the reflectance decreases abruptly at first, then increase slightly and decrease at last. In fact, the long structures make it possible to obtain multiple rebounds of the incident light inside the antireflective structure and therefore to increase the probability of light 
transmission. Since the height of nanostructures increase with the etching time, long nanostructures lead to a high production cost. Therefore, a trade-off is to be found between the more performing long nanostructures and the high production cost.

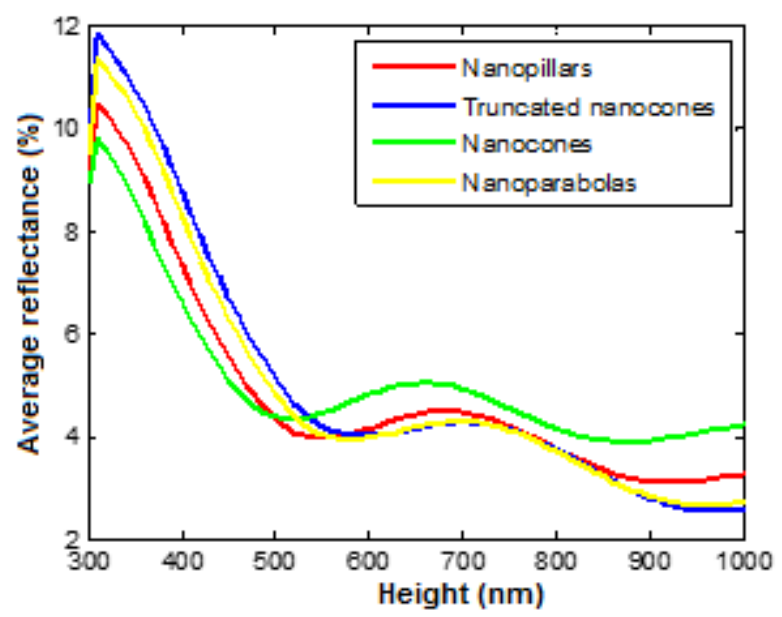

Figure 5: Average reflectance as a function of the height of the nanostructures.

Figure 6.a compares the reflectance of the four types of antireflective structures optimized in this study. The performance of a quarter-wavelength $\mathrm{SiN}_{\mathrm{x}}$ layer is also shown as reference. It can be seen that the antireflective structures perform better than the planar $\mathrm{SiN}_{\mathrm{x}}$ over the wavelength range 300$1100 \mathrm{~nm}$. Particularly, the conical and parabolic shapes give the best antireflective performance. This might be due to a better graded refractive index (GRIN). Indeed, a best GRIN is obtained when the volume fraction (f) is nearly one at the bottom of the nanostructures and zero at the top of them.
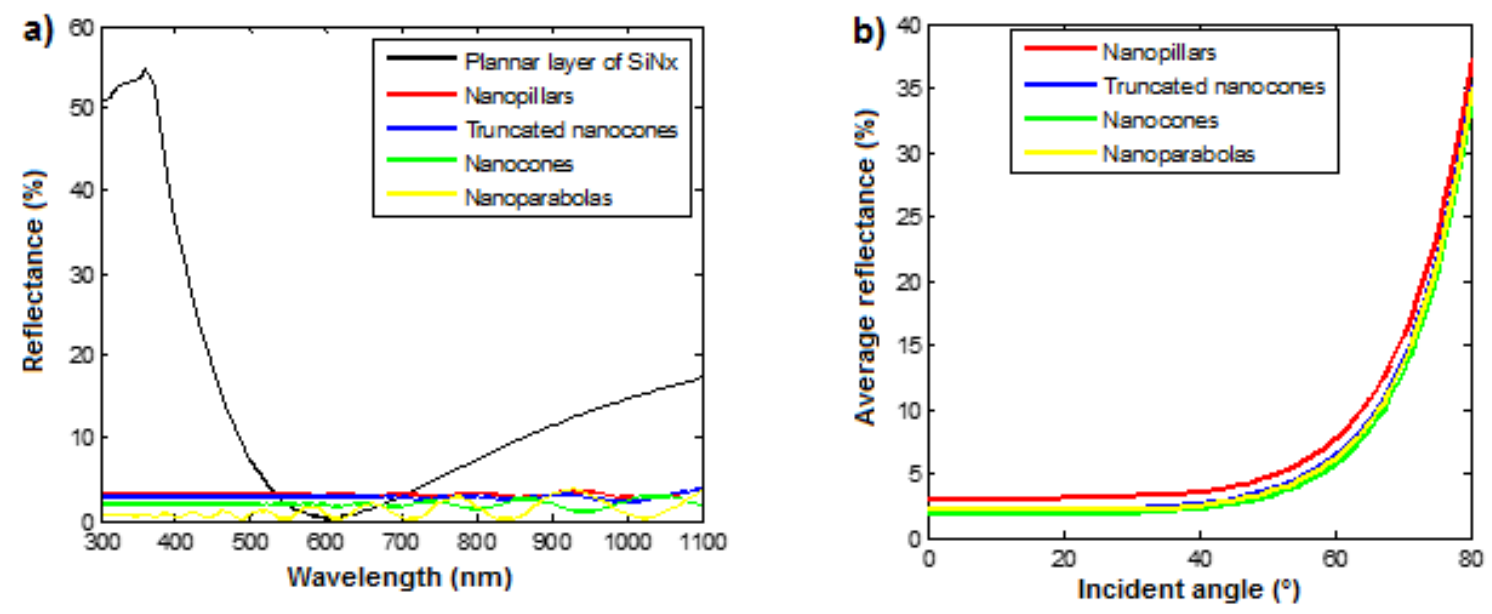

Figure 6: (a) Reflectance as function of the wavelength for the AR nanostructures and a SiNx layer used as reference; (b) Dependence of the reflection on the incident angles.

The performances of the AR structures studied in this work are summarized in Table 3. These performances are obtained under normal incidence and in the wavelength range $300-1100 \mathrm{~nm}$. 
Table 4: Summary of the performance of the antireflective structures

\begin{tabular}{|l|l|l|}
\hline AR structures & $\mathbf{R w}[\%]$ & $\mathbf{J s c}\left[\mathbf{m A} / \mathbf{c m}^{\mathbf{2}}\right]$ \\
\hline Pillars & 3.0792 & 41.1799 \\
\hline Cones & 2.7507 & 41.3114 \\
\hline Truncated cones & 2.0067 & 41.6274 \\
\hline Parabolas & 1.2222 & 41.9607 \\
\hline
\end{tabular}

The effect of incident angle on the antireflective performances given by these AR structures is also considered. Figure 6.b shows that the reflectance is only sensitive to angles greater than $60^{\circ}$. The conical and parabolic shape give the best antireflective performances. But, in practice, a conical nanostructure is easier to fabricate than a parabolic one. As their antireflective performances are almost the same, the conical nanostructure can be considered as the optimal shape. The fabrication of this structure is described in the next section.

\section{Fabrication of silicon nanocones by MACE method}

Dry etching with nanoscale mask patterns is the commonly used method to fabricate subwavelengthscale silicon nanostructures [57]. However, this method is complex, expensive, and unsuitable for mass production. Metal assisted chemical etching (MACE), based on the strong catalytic activity of metal in an aqueous solution, is an alternative to produce silicon nanostructures for electronic and optoelectronic devices. It is a simple, fast, cost-effective, and high throughput method for fabricating various silicon nanostructures without any sophisticated equipment.

In this work, silicon nanocones (SNCs) were fabricated via silicon nanowires (SNWs). Silicon samples were first cleaned using acetone, ethanol and deionized water in the ultrasonic bath during 15 minutes. After this cleaning, the samples were immersed in a piranha solution $\left(\mathrm{H}_{2} \mathrm{SO}_{4} / \mathrm{H}_{2} \mathrm{O}_{2}\right)$ during 10 minutes to eliminate any organic trace. The last steps of the cleaning process were the removing of the native oxide $\left(\mathrm{SiO}_{2}\right)$ using diluted $\mathrm{HF}$ solution and the rinse of the samples with deionized water.

After cleaning, the samples were immersed in the $\mathrm{HF} / \mathrm{AgNO}_{3}(4.8 \mathrm{M} / 0.02 \mathrm{M})$ solution during 5 minutes. This solution allows to deposit $\mathrm{Ag}$ nanoparticles on the silicon surface. Then, the samples were directly immersed in $\mathrm{HF} / \mathrm{H}_{2} \mathrm{O}_{2}\left(4.8 \mathrm{M} / 1.176 .10^{-3} \mathrm{M}\right)$ mixture. In order to remove the Ag waste, a diluted $\mathrm{HNO}_{3}$ solution was used. Finally, vertical SNWs were obtained on the crystalline silicon substrate. A SEM image of the sample is shown in Figure 7. 


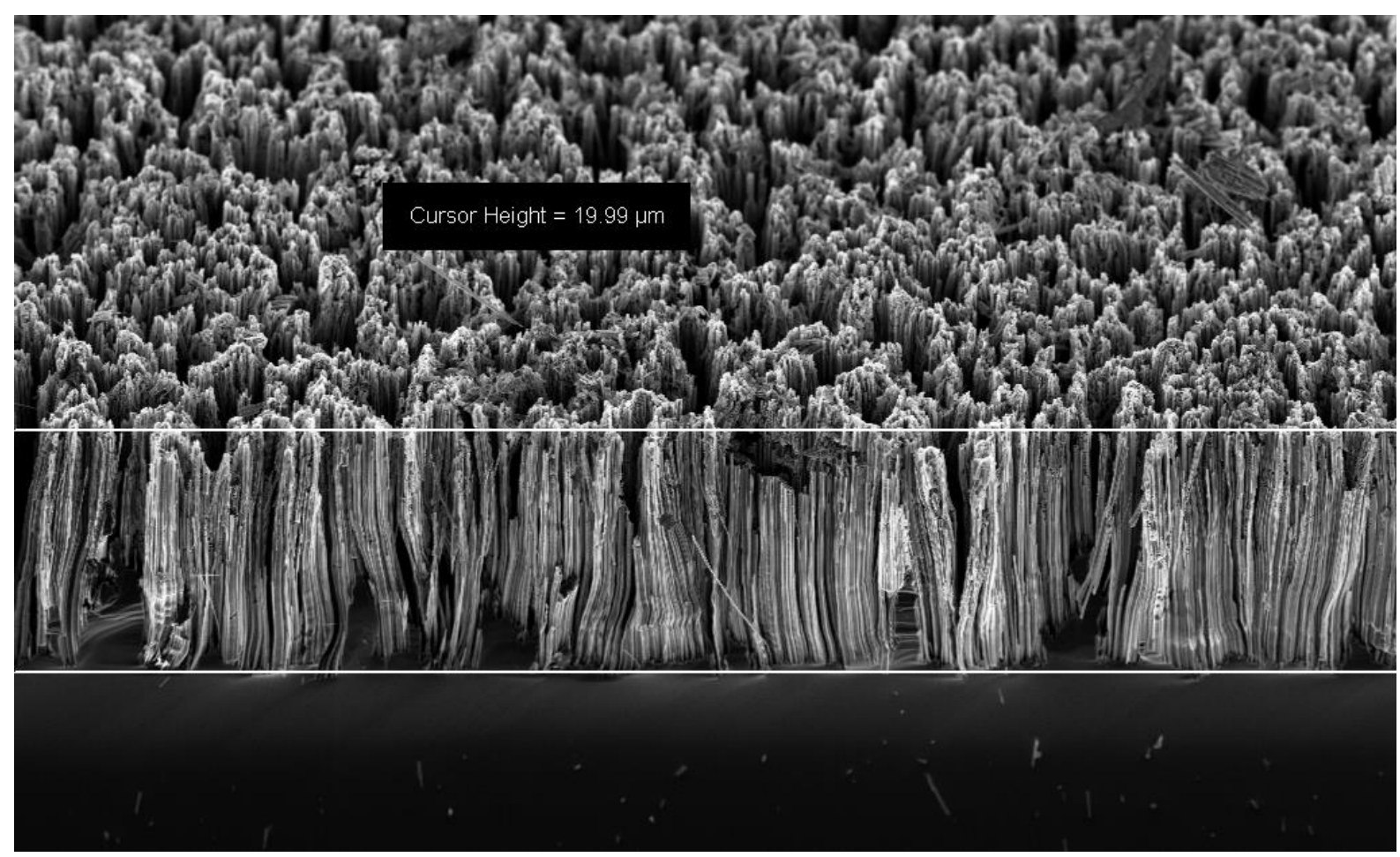

Figure 7: SEM image of silicon nanowires fabricated by MACE method on a c-Si substrate.

Once the SNWs were obtained, they were treated with a mixture of $\mathrm{HF} / \mathrm{AgNO}_{3} / \mathrm{H}_{2} \mathrm{O}_{2}$ in order to fabricate SNCs. Indeed, this mixture has a dual function: it leads to the selective deposition of $\mathrm{Ag}$ clusters at the SNW tips and at the same time performs the etching of the silicon surface. The Ag cluster deposition and removal processes were then repeated several times under well-controlled chemical conditions in order to yield silicon nanowires with different morphology, focusing on the ultimate goal to produce silicon nanocones. Finally, a $\mathrm{HNO}_{3}$ solution was used to remove the residual silver.

Reflectance spectra from the fabricated silicon nanocones were measured using a UV-VIS-NIR spectrophotometer and the results were compared with the calculated one. It can be seen in Figure 8 that the experimental results confirm the theoretical ones. However, the measured reflectance is slightly higher than the calculated one because a metallic grid was deposited on the SNCs arrays as surface contact. 


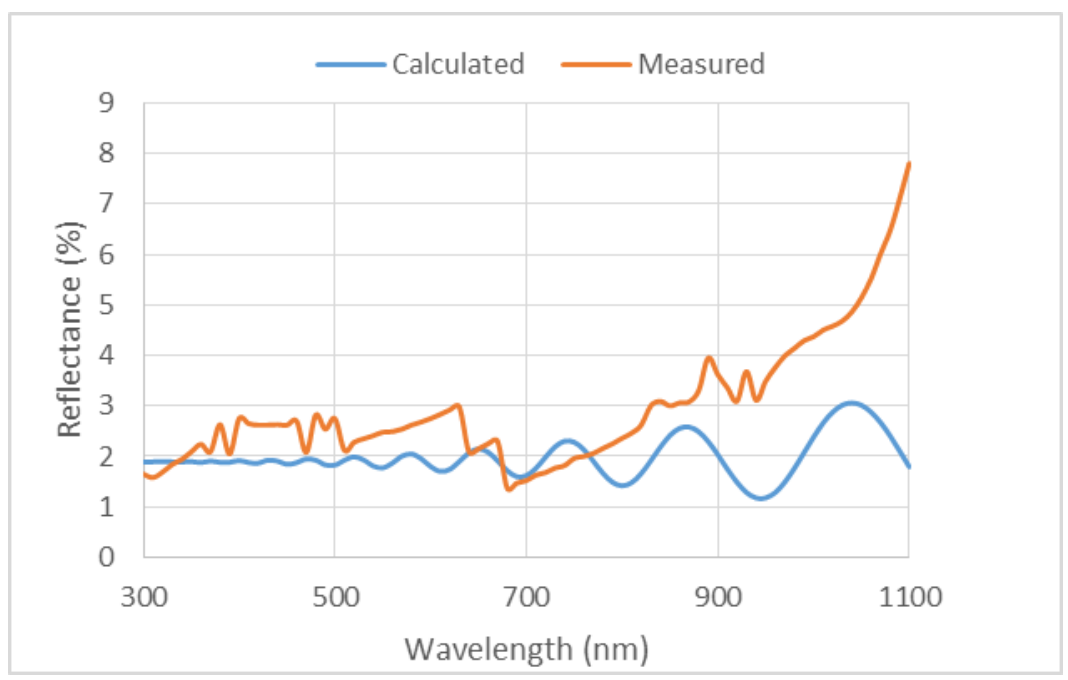

Figure 8: Reflectance spectra from fabricated SNCs: calculated (blue) and measured (red).

\section{Conclusion}

We have reviewed recent advances in various silicon nanostructures used for antireflection and light trapping in crystalline silicon solar cells, such as nanopyramids, nanopillars, nanocones, and nanoparaboloids, with particular focus on the fabrication techniques, the structural parameters and the resulting performance. Using the transfer matrix method, we have simulated and optimized three silicon nanostructure shapes and found that nanocones and nanoparaboloids outperform nanopillars. They exhibit nearly the same antireflective performance, reducing the average reflectance of the crystalline silicon surface below $2 \%$ in the wavelength range 300-1100 nm and under normal incidence. Our simulation and optimization results showed that with these two silicon nanostructure shapes short-circuit current densities of 41.62 and $41.96 \mathrm{~mA} / \mathrm{cm}^{2}$ can be expected, respectively. Therefore, this is a confirmation of the great potential of these nanostructures to enhance the power conversion efficiency of crystalline silicon solar cells. We have fabricated a conical AR nanostructure by MACE method and measured its average reflectance. We have noticed a small deviation in the average reflectance between the measured $(2.96 \%)$ and the calculated one $(1.98 \%)$.

\section{Complementary informations on authors:}

Babacar DIENG: dieng.babacar@ugb.edu.sn, https://www.researchgate.net/profile/Babacar Dieng

Modou BEYE: almodu@yahoo.fr, https://www.researchgate.net/profile/Modou Beye

Moussa TOURE: m.toure5053@zig.univ.sn, https://www.researchgate.net/profile/M Toure 
Djicknoum DIOUF: djicknoum.diouf@ugb.edu.sn, https://www.researchgate.net/profile/Diicknoum Diouf3

\section{Acknowledgements:}

B. Dieng acknowledge financial support from the CEA-MITIC.

\section{REFERENCES}

1. M. A. Green, Y. Hishikawa, W. Warta, E. D. Dunlop, D. H. Levi, J. Hohl-Ebinger, A. W. Y. Ho-Baillie, Prog Photovolt Res Appl., Vol. 25, p 668-676 (2017).

2. International Technology Roadmap for Photovoltaic (ITRPV), 9-th Edition, p 1-76 (2018).

3. A. R. Barron, Materials Today, Vol. 18, (2015).

4. S. Koynov, M. S. Brandt, M. Stutzmann, Applied Physics Letters, Vol. 88, p 203107-1-203107-3 (2006).

5. H. Savin, P. Repo, G. von Gastrow, P. Ortega, E. Calle, M. Garín, R. Alcubilla, Nature Nanotechnology, Vol. 10, p 624-629 (2015).

6. Y-F. Huang, S. Chattopadhyay, Y-J. Jen, C-Y Peng, T-A. Liu, Y-K. Hsu, C-L. Pang, H-C. Lo, C-H. Hsu, YH. Chang, C-S. Lee, K-H. Chen, L-C. Chen, Nature Nanotechnology, Vol. 2, p 770-774 (2007).

7. C-H. Sun, P. Jiang, B. Jiang, Applied Physics Letter, Vol. 92, p 061112-1-061112-3 (2008).

8. S. A. Boden and D. M. Bagnall, Applied Physics Letters, Vol. 93, p 133108-1-133108-3 (2008).

9. S. A. Boden, D. M. Bagnall, Prog. Photovolt: Res. Appl., Vol. 18, p 195-203 (2010).

10. S. J. Cho, T. An, Jin Y. Kim, J. Sung, G. Lim, Chem. Commun., Vol. 47, p 6108-6110 (2011).

11. C. I. Yeo, J. B. Kim, Y. M. Song, Y. T. Lee, Nanoscale Research Letters, Vol. 8, p 2-7 (2013).

12. S. C. Baker-Finch, K. R. Mclntosh, Prog. Photovolt: Res. Appl., Vol. 19, p 406-416 (2011).

13. L. Yang, Y. Liu, Y. Wang, W. Chen, Q. Chen, J. Wua, A. Kuznetsov, X. Du, Solar Energy Materials \& Solar Cells, Vol. 166, p 121-126 (2017).

14. M. Moreno, D. Daineka, P. Roca i Cabarrocas, Solar Energy Materials \& Solar Cells, Vol. 94, p 733-737 (2010).

15. S. C. Baker-Finch, K. R. McIntosh, Prog. Photovolt: Res. Appl., Vol. 20, p 51-61 (2012).

16. Y. Wang, L. Yang, Y. Liu, Z. Mei, W. Chen, J. Li, H. Liang, A. Kuznetsov, D. Xiaolong, Scientific Reports, Vol. 5:10843, p 1-6 (2015).

17. H-P. Wang, A-C. Li, T-Y. Lin, J-H. He, Nano Energy, Vol. 8, p 6484-6490 (2016).

18. V. Depauw, C. Trompoukis, I. Massiot, W. Chen, A. Dmitriev, P. Roca i Cabarrocas, I. Gordon, J. Poortmans, Nano Futures, Vol. 1, p 1-8 (2017).

19. B. W. Schneider, N. N. La, S. Baker-Finch, T. P. White, Optics Express, Vol. 22, p A1422-A1430, (2014).

20. A. Mavrokefalos, S. E. Han, S. Yerci, M. S. Branham, G. Chen, Nano Lett., Vol. 12, p 2792-2796 (2012).

21. S. Sivasubramaniam, M. M. Alkaisi, Microelectronic Engineering, Vol. 119, p 146-150 (2014).

22. S. Sivasubramaniam, A. Faramus, R. D. Tilley, M. M. Alkaisi, Journal of Renewable and Sustainable Energy, Vol. 6, p 011204-1-011204-8 (2014).

23. S. Zhou, Z. Yang, P. Gao, X. Li, Xi Yang, D. Wang, J. He, Z. Ying, J. Ye, Nanoscale Research Letters, Vol. 11, p 1-8 (2016).

24. A. P. Amalathas, M. M. Alkaisi, Materials Science in Semiconductor Processing, Vol. 57, p 54-58 (2017).

25. H. Xu, Nan Lu, D. Qi, J. Hao, L. Gao, B. Zhang, L. Chi, Small, Vol. 4, p 1972-1975 (2008). 
26. W-L. Min, B. Jiang, and P. Jiang, Adv. Mater., Vol. 20, p 1-5, (2008).

27. K. J. Morton, G. Nieberg, S. Bai, S. Y Chou, Nanotechnology, Vol. 19, p 1-6 (2008).

28. H-P. Wang, K-Y. Lai, Y-R. Lin, C-A. Lin, Jr-H. He, Langmuir, Vol. 26, p 12855-12858 (2010).

29. Y. Li, J. Zhang, B. Yang, Nano Today, Vol. 5, p 117-127 (2010).

30. B. M. Philips, P. Jiang, B. Jiang, Applied Physics Letters, Vol. 99, 191103-1191103-3 (2011).

31. H-P. Wang, K-T. Tsai, K-Y. Lai, T-C. Wei, Y-L. Wang, Jr-H. He, Optics Express, Vol. 20, p A94-A103 (2012).

32. P. Spinelli, M. A. Verschuuren, A. Polman, Nature Communications, Vol. 3, p 1- 5 (2012).

33. R. Kapadia, Z. Fan, K. Takei, A. Javey, Nano Energy, Vol. 1, p 132-144 (2012).

34. A. Asadollahbaik, S. A. Boden, M. D. B. Charlton, D. N. R. Payne, S. Cox, D. M. Bagnall, Optics Express, Vol. 22, p A402-A415 (2014).

35. J. Proust, A-L. Fehrembach, F. Bedu, I. Ozerov, N. Bonod, Scientific reports, Vol. 6, p 1-8 (2016).

36. Z. Fan, R. Kapadia, P. W. Leu, X. Zhang, Y-L. Chueh, K. Takei, K. Yu, A. Jamshidi, A. A. Rathore, D.I J. Ruebusch, M. Wu, A. Javey, Nano Lett., Vol. 10, p 3823-3827, (2010).

37. B. Hua, B. Wang, Miao Yu, P. W. Leu, Z. Fan, Nano Energy, Vol. 2, p 951-957 (2013).

38. P. Spinelli, A. Polman, IEEE Journal of Photovoltaics, Vol. 4, p 554-559 (2014).

39. Y. Wang, N. Lu, H. Xu, G. Shi, M. Xu, X. Lin, H. Li, W. Wang, D. Qi, Y. Lu, L. Chi, Nano Res, Vol. 3, p 520-527 (2010).

40. H. Park, D. Shin, G. Kang, S. Baek, K. Kim and W. J. Padilla, Adv. Mater., Vol. 23, p 5796-5800 (2011).

41. Y. Quu, H-C. Hao, J. Zhou, L. Lu, Optics Express, Vol. 20, p 22087-22094 (2012).

42. C-M Hsu, C. Battaglia, C. Pahud, Z. Ruan, F-J. Haug, S. Fan, C. Ballif, Y. Cui, Adv. Energy Mater., Vol. 2, p 628-633 (2012).

43. S. Jeong, M. D. McGehee \& Y Cui, Nature Communications, Vol. 4, p 1-7 (2013).

44. K-H. Tsui, Q. Lin , H. Chou, Q. Zhang , H. Fu, P. Qi, Z. Fan, Adv. Mater., Vol. 26, p 2805-2811 (2014).

45. Q. Lin, S-F. Leung, L. Lu, X. Chen, Z. Chen, H. Tang, W. Su, D. Li, Z. Fan, acsnano, Vol. 8, p 64846490 (2014).

46. X. Ye, J. Huang, R. F. Ni, Z. Yi, X. D. Jiang, W. G. Zheng, Vol. 17, p 192-197 (2015).

47. A. Rahman, A. Ashraf, H. Xin, X. Tong, P. Sutter, M. D. Eisaman, C. T. Black, Nature Communication, Vol. 6, p 1-6 (2015).

48. J. Li, H. Yu, S. M. Wong, G. Zhang, G-Q. Lo, D-L. Kwong, J. Phys. D: Appl. Phys., Vol. 43, p 1-7 (2010).

49. B. Wang,P. W Leu, Nanotechnology, Vol. 23, p 1-7 (2012).

50. B. Hua, Q. Lin, Q. Zhang, Z. Fan, Nanoscale, Vol. 5, p $6627-6640$ (2013).

51. H. Butt, Q. Dai, R. Rajasekharan, T. D. Wilkinson, G. A. J. Amaratunga, Applied Physics Letters, Vol. 99, p 133105-1-133105-3 (2011).

52. K. X. Wang, Z. Yu, V. Liu, Y. Cui, S. Fan, Nano Lett. Vol. 12, p 1616-1619 (2012).

53. R. Dewan, S. Fisher, B. Meyer-Rochow, Y. Özdemir, S. Hamraz, D. Knipp, Bioinspiration and biomimetics, Vol. 7, p 1-8 (2012).

54. K. Shinotsuka, K. Hongo, K. Dai, S. Hirama, and Y. Hatta, Japanese Journal of Applied Physics, Vol. 56, p 022202-1-022202-8 (2017).

55. M.C. Troparevsky, A.S. Sabau, A.R. Lupini, Z. Zhang, Optics Express Vol.18, No.24, p 24715-24721 (2010).

56. C. Schinke, P.C Peest, J. Schmidt, R. Brendel, K. Bothe, M.R. Vogt, I. Kröger, S. Winter, A. Schirmacher, S. Lim, H. T. Nguyen, D. MacDonald, AIP Advances, Vol. 5, p. 067168-1-067168-22 (2015).

57. J. Lui, M. Ashmkhan, B. Wang, and F. Yi, Applied Surface Science, Vol. 258, p 8825-8830 (2012). 
Important: Articles are published under the responsability of authors, in particular concerning the respect of copyrights. Readers are aware that the contents of published articles may involve hazardous experiments if reproduced; the reproduction of experimental procedures described in articles is under the responsability of readers and their own analysis of potential danger.

\section{Reprint freely distributable - Open access article}

Materials and Devices is an Open Access journal which publishes original, and peer-reviewed papers accessible only via internet, freely for all. Your published article can be freely downloaded, and self archiving of your paper is allowed and encouraged!

We apply « the principles of transparency and best practice in scholarly publishing » as defined by the Committee on Publication Ethics (COPE), the Directory of Open Access Journals (DOAJ), and the Open Access Scholarly Publishers Organization (OASPA). The journal has thus been worked out in such a way as complying with the requirements issued by OASPA and DOAJ in order to apply to these organizations soon.

Copyright on any article in Materials and Devices is retained by the author(s) under the Creative Commons

(Attribution-NonCommercial-NoDerivatives 4.0 International (CC BY-NC-ND 4.0)), which is favourable

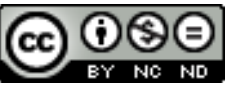

to authors.

Aims and Scope of the journal : the topics covered by the journal are wide, Materials and Devices aims at publishing papers on all aspects related to materials (including experimental techniques and methods), and devices in a wide sense provided they integrate specific materials. Works in relation with sustainable development are welcome. The journal publishes several types of papers : A: regular papers, $L$ : short papers, $R$ : review papers, $T$ : technical papers, Ur : Unexpected and « negative » results, Conf: conference papers.

(see details in the site of the journal: http://materialsanddevices.co-ac.com)

We want to maintain Materials and Devices Open Access and free of charge thanks to volunteerism, the journal is managed by scientists for science! You are welcome if you desire to join the team!

Advertising in our pages helps us! Companies selling scientific equipments and technologies are particularly relevant for ads in several places to inform about their products (in article pages as below, journal site, published volumes pages, ...). Corporate sponsorship is also welcome! 